INOBIS: Jurnal Inovasi Bisnis dan Manajemen Indonesia

Volume 1, Nomor 3, Juni 2018

I Gusti Ayu Ari Warmadewi; Putu Saroyini Piartrini

\title{
Peran Stress Kerja Pada Hubungan Persepsi Konflik Keluarga - Pekerjaan Dengan Kepuasan Kerja
}

\author{
I Gusti Ayu Ari Warmadewi \\ yugekari@gmail.com \\ Putu Saroyini Piartrini \\ royetrini@unud.ac.id \\ Universitas Udayana
}

\begin{abstract}
Abstrak
Penelitian ini mengungkapkan peran stress kerja pada hubungan Persepsi Konflik antara pekerjaan dengan Keluarga yang dialami oleh karyawan CV Bali Aquarium yang pada satu sisi menghadapi tuntutan kerja yang melebihi jam kerja normal, kondisi kerja yang berisiko terhadap keselamatan jiwa karena harus menyelam di laut untuk menanam terumbu karang dan di sisi yang lain memiliki kewajiban sosial sebagai warga masyarakat dan anggota keluarga. Dari perspektif Job demand - control Model penelitian ini mengukur stres kerja yang dialami karyawan, dalam hubungan antara konflik yang dialami antara pekerjaan dan keluarga dengan kepuasan kerja yang dibahas dari perspektif Two Factors Theory. Data dikumpulkan dari karyawan perusahaan yang berjumlah 39 orang untuk pengujian hipotesis. Temuan penelitian mengungkapkan bahwa persepsi konflik pekerjaan - keluarga berkorelasi dengan stres kerja dan kepuasan kerja. Stres kerja menjadi mediator hubungan antara persepsi konflik pekerjaan dengan keluarga dengan kepuasan kerja. Implikasi temuan penelitian merekomendasikan bahwa manajemen perlu mengendalikan stres dengan mengurangi beban kerja karyawan yang padat dan memberikan waktu istirahat yang cukup dan memberikan waktu untuk melaksanakan aktivitas lain. Kondisi ini mengakibatkan pekerrjaan tidak menarik bagi karyawan dan karyawan merasa tidak diakui pencapaian yang dimiliki.
\end{abstract}

Kata kunci: Stres kerja, konnflik pekerjaan-keluarga, kepuasan kerja.

\section{Latar Belakang Masalah}

CV. Bali Aquarium merupakan perusahaan yang bergerak dibidang eksportir ikan hias dan terumbu karang (coral)yang didirikan pada tahun 1989 dengan tujuan pasar Eropa dan Asia. Perusahaan mempekerjakan 50 orang karyawan yang dituntut mampu bekerja dengan standar kerja yang tinggi. Karyawan harus siap untuk bekerja lembur, maupun bekerja diluar jam kerja normal untuk melakukan pengiriman ikan maupun terumbu karang pada pagi hari, maka karyawan harus bekerja sejak dini hari pukul 02.00. Pekerjaan juga memiliki resiko keselamatan yang tinggi karena harus menyelam untuk menanam maupun memanen terumbu karang. Sebagai mahluk sosial karyawan juga memiliki peran sosial. Peran sosial ini meliputi peran sebagai ayah, ibu, warga masyarakat/banjar yang harus dilaksanakan pada saat yang sama dengan pelaksanaan pekerjaan dari perusahaan.

Tuntutan pekerjaan dan pelaksanaan peran sosial individu karyawan dapat memicu stress, yang didefinisikan sebagai kondisi tertekan yang di alami karyawan, akibat tuntutan pekerjaan dan pelaksanaan peran sosial yang melebihi kapasitas yang dimiliki seorang karyawan. Berdasarkan the job demands-control model (Karasek, 1979) stres adalah dampak interaktif antara tuntutan pekerjaan dan kontrol individu. Stres kerja dapat terjadi karena pekerjaan 
INOBIS: Jurnal Inovasi Bisnis dan Manajemen Indonesia

Volume 1, Nomor 3, Juni 2018

\section{Gusti Ayu Ari Warmadewi; Putu Saroyini Piartrini}

karyawan terdapat tuntutan pekerjaan yang tinggi namun kendali terhadap pekerjaan tersebut sangat rendah. Kendali akan semakin meningkat ketika individu mendapatkan dukungan sosial dari rekan kerja atau atasannya. Alves et al. (2004) mengukur stres kerja dalam 3 dimensi yaitu: Demands, berkaitan dengan tuntutan kecepatan menyelesaikan tugas-tugas dan proses kerja. Contol, berkaitan dengan penggunaan kemampuan dan pengembangan kemampuan. Support, berkaitan dengan hubungan pekerja dengan rekan-rekan dan atasan.

Studi awal dilakukan dengan mewawancarai 5 orang karyawan di CV. Bali Aquarium yaitu Dedi, Desi, Sari, Budi dan Joko (nama asli disamarkan). Hasil wawancara menunjukkan bahwa kelima karyawan mengeluhkan tuntutan kerja yang melebihi kapasitas dan merasa bekerja di bawah tekanan, karena pihak manajemen menuntut karyawan untuk bekerja cepat dengan banyak variasi tugas yang harus dilakukan, harus siap siaga apabila terjadi masalah dalam pengiriman barang, serta siap bekerja di luar jam kantor. Karyawan juga dihadapkan pada pekerjaan yang memiliki risiko tinggi, ketika menyelam untuk memanen terumbu karang di laut, akibatnya tidak jarang karyawan mengalami masalah fisik seperti kulit gatal-gatal akibat air laut. Penelitian yang dilakukan oleh Singh dan Nayak (2015) dengan sampel polisi di India, menemukan bahwa konflik pekerjaan-keluarga menimbulkan stres dan mempengaruhi kepuasan kerja. Karyawan yang berada yang mengalami stres kerja melaporkan kepuasan kerja yang rendah (Mahfudz, 2017).

Peran ganda yang dimiliki individu karyawan yang dituntut melaksanakan dua aktifitas pada saat yang bersamaan, disertai dengan ketidakmampuan dalam menyeimbangkan kedua peran ini dapat memicu timbulnya konflik peran. Konflik peran didefinisikan sebagai dua tekanan atau lebih, yang menyebabkan individu kesulitan dalam memenuhi peran satu sama lain (Kahn et al.1964). Salah satu wujud konflik peran yang dialami oleh karyawan adalah konflik pekerjaan-keluarga. Netemeyer et al. (1996) menyatakan konflik pekerjaan-keluarga merupakan konflik antara pekerjaan dengan kehidupan keluarga. menyatakan pengukuran konflik pekerjaan-keluarga meliputi 2 dimensi yaitu sebagai berikut: time-based conflict berkaitan dengan waktu yang dibutuhkan untuk menjalankan salah satu tuntutan (pekerjaan atau keluarga) akan mengurangi waktu untuk menjalankan tuntutan lainnya (pekerjaan atau keluarga). Strain based conflict berkaitan dengan tekanan dari salah satu peran yang akan mempengaruhi kinerja peran lainnya (Netemeyer et al.,1996).

Wawancara dengan lima orang karyawan CV Bali aquarium menunjukkan adanya konflik pekerjaan-keluarga. Karyawan bernama Dedi (nama asli disamarkan) mengeluhkan bahwa "pekerjaannya membutuhkan banyak waktu sehingga waktu bersama keluarga menjadi berkurang"., sementara Sari (nama asli disamarkan) menyatakan bahwa "pekerjaannya menguras tenaga, sehingga ketika sampai di rumah ia terlalu lelah untuk sekedar bermain bersama anaknya". Desi (nama asli disamarkan) menyatakan bahwa "tuntutan dari pekerjaan membuatnya merasa sulit untuk memenuhi tanggung jawab kepada keluarga". Joko (nama asli disamarkan) dan karyawan bernama Budi (nama asli disamarkan) menyatakan bahwa "Karyawan harus tetap bekerja meski di hari libur, hal tersebut mengganggu waktu liburan mereka dengan keluarga". Karyawan yang mengalami konflik pekerjaan-keluarga yang tinggi berimplikasi kepada stres kerja, diakibatkan oleh ketidakmampuan seorang karyawan dalam menyeimbangkan tuntutan kedua peran yang dimiliki sehingga secara langsung maupun langsung dapat menyebabkan kepuasan kerja seorang individu menjadi rendah (Gao et al., 2013; Rathi dan Barath, 2012).

Studi awal juga mengungkapkan gejala ketidakpuasan kerja sebagaimana diungkapkan oleh beberapa karyawan berikut; Dedi (nama asli disamarkan) mengungkapkan "gaji yang saya terima tidak sebanding dengan beban kerja yang saya emban". Desi (nama asli disamarkan) juga menjelaskan bahwa "saya kurang menyukai pekerjaan saya di perusahaan ini". Sari (nama 
INOBIS: Jurnal Inovasi Bisnis dan Manajemen Indonesia

Volume 1, Nomor 3, Juni 2018

\section{Gusti Ayu Ari Warmadewi; Putu Saroyini Piartrini}

asli disamarkan) menyatakan bahwa "saya kurang dapat bekerja sama dengan rekan-rekan di perusahaan ini". Budi (nama asli disamarkan) menyatakan bahwa "saya terpaksa menerima pekerjaan ini, karena saat ini mencari pekerjaan sangat susah". Joko (nama asli disamarkan) menyatakan bahwa "atasan saya kurang memperhatikan kondisi karyawannya".

Anggasta dan Margaretha (2013) menyatakan bahwa kepuasan kerja yang rendah berdampak buruk bagi kinerja karyawan tersebut, rendahnya loyalitas dan komitmen karyawan pada perusahaan, sehingga berdampak pada rendahnya keuntungan yang diterima perusahaan. Singh dan Nayak (2015) mengungkapkan bahwa kepuasan kerja karyawan dapat disebabkan oleh beberapa faktor, salah satunya yaitu konflik pekerjaan-keluarga.

Berdasarkan indikasi perilaku terdapat gejala kepuasan kerja yang rendah berhubungan dengan stres kerja dan konflik peran yang dialami karyawan, maka penelitian ini bertujuan menguji hubungan kepuasan kerja karyawan berkolerasi dengan konflik pekerjaan-keluarga dan stres kerja. Secara rinci masalah peneluitian dirumuskan sebagai berikut : 1) Bagaimana pengaruh konflik pekerjaan-keluargaterhadap kepuasan kerja karyawan di CV. Bali Aquarium?; 2)Bagaimana pengaruh konflik pekerjaan-keluarga terhadap stres kerja karyawan di CV. Bali Aquarium?; 3)Bagaimana pengaruh stres kerja terhadap kepuasan kerja karyawan di CV. Bali Aquarium?.

Tujuan dalam penelitian ini adalah 1) Menganalisis pengaruh konflik pekerjaan-keluarga terhadap kepuasan kerja karyawan di CV. Bali Aquarium; 2) Menganalisis pengaruh konflik pekerjaan-keluarga terhadap stres kerja karyawan di CV. Bali Aquarium; dan 3) Menganalisis pengaruh stres kerja terhadap kepuasan kerja karyawan di CV. Bali Aquarium. Temuan penelitian ini diharapkan mampu memperkaya bukti empiris hubungan konflik pekerjaankeluarga, stres kerja, dengan kepuasan kerja karyawan di CV. Bali Aquarium dan memberikan masukan kepada manajemen CV. Bali Aquarium untuk meningkatkan kepuasan kerja karyawan dengan meminimalisasi konflik pekerjaan-keluarga dan menurunkan stres kerja.

\section{Landasan Teori Dan Kajian Pustaka}

\subsection{Konflik Peran}

Teori peran menyatakan bahwa individu memiliki peran dalam kehidupannya sebagai pelaku sosial (Kahn et al. 1964). Peran individu mengharapkan individu berperilaku sesuai dengan posisi sosial yang ditempatinya, baik dalam lingkungan kerja, keluarga maupun masyarakat. Peran yang dimiliki setiap individu merupakan seperangkat hak, kewajiban, harapan, perilaku dan norma seseorang untuk memenuhi perannya. Lingkungan mempengaruhi harapan individu mengenai perilaku terhadap peran mereka. Harapan tersebut meliputi normanorma atau tekanan untuk bertindak dalam cara tertentu. Lingkungan organisasi yang berubahubah dan tidak sesuai dengan harapan, akan memunculkan konflik dan tekanan dalam menjalankan peran tersebut atau yang sering disebut dengan konflik peran. Konflik peran terjadi apabila terdapat dua tekanan atau lebih yang terjadi secara bersamaan yang ditujukan

pada individu. Konflik peran berhubungan dengan konflik pekerjaan-keluarga yang berakibat pada tekanan timbal balik yang tidak konsisten terkait dengan peran dalam pekerjaan dan domain keluarga. Konflik pekerjaan-keluarga merupakan interrole conflict (konflik antar peran) yang timbul sebagai akibat dari peran dalam pekerjaan dan peran dalam keluarga saling menuntut untuk dipenuhi (Kaliath dan Kaliath., 2013). Menurut Adkins dan Premeaux (2012) terdapat harapan terkait dengan peran tertentu (pekerjaan) dan harapan tersebut menyebabkan individu gagal memenuhi tanggung jawab peran lainnya (keluarga), hal ini menyebabkan kinerja yang lemah dari peran tersebut dan mengarah pada konflik pekerjaan-keluarga. Konflik 
INOBIS: Jurnal Inovasi Bisnis dan Manajemen Indonesia

Volume 1, Nomor 3, Juni 2018

\section{Gusti Ayu Ari Warmadewi; Putu Saroyini Piartrini}

pekerjaan-keluarga merupakan konflik antar peran yang terjadi kepada individu sebagai akibat dari ketidakmampuan dalam menyelaraskan kedua peran tersebut (Netemeyer et al. 1996). Saat ini semakin banyak karyawan yang mendapati diri mereka berjuang untuk menyeimbangkan tuntutan antara pekerjaan dan tanggung jawab dalam keluarga, sehingga mendorong terjadinya konflik antara pekerjaan dan kehidupan keluarga (Alazzam et al. 2017).

Konflik pekerjaan-keluarga disebabkan oleh kondisi lingkungan pekerjaan maupun dari keluarga. Netemeyer et al. (1996), mengidentifikasikan dua faktor konflik pekerjaan-keluarga, yaitu: 1) Time-based conflict. Waktu yang dibutuhkan dalam menjalankan salah satu tuntutan (pekerjaan atau keluarga) akan mengurangi waktu untuk menjalankan tuntutan lainnya (keluarga atau pekerjaan) seperti penggunaan hari libur untuk bekerja dan 2) Strain-based conflict. Terjadi tekanan dari salah satu peran yang akan mempengaruhi kinerja peran lainnya seperti tuntutan dalam bekerja menggangu kehidupan keluarga.Konflik pekerjaan-keluarga berdampak pada ketidakpuasan kerja yang pada akhirnya akan berimbas pada penurunan kinerja dan komitmen organisasi (Shacklock dan Brunetto, 2012); menyebabkan stres kerja akibat dari ketidakmampuan dalam menyelaraskan masing-masing peran, skemudian berdampak pada kepuasan kerja yang menurun (Gozukara dan Colakoglu, 2015). Gao et al. (2013) menemukan bahwa konflik pekerjaan-keluarga menghasilkan tekanan psikologis yang lebih besar dan menurunkan kepuasan kerja secara signifikan.

\subsection{Stres Kerja}

Teori the job demands-control model yang dikembangkan oleh Karasek (1979) mengungkapkan bahwa stres kerja adalah dampak interaktif antara tuntutan pekerjaan dan control. Model ini diperluas dengan menambahkan faktor yang akan menentukan tingkat stres seseorang, yaitu dukungan sosial (Karasek dan Theorell, 1990). Model ini kemudian dikenal menjadi the job demands-control-support (JDCS). Stres kerja dapat terjadi karena dalam pekerjaan karyawan terdapat tuntutan pekerjaan yang tinggi namun kendali terhadap pekerjaan tersebut sangat rendah. Kendali akan semakin meningkat ketika individu mendapatkan dukungan sosial dari rekan kerja atau atasannya. Stres adalah reaksi negatif terhadap peristiwa yang tidak mampu diatasi oleh individu (Lee et al. 2014), Stres kerja merupakan perasaan tertekan yang dialami karyawan dalam menghadapi pekerjaan yang ditandai dengan indikator perilaku perasaan tidak tenang, kecemasan, emosi yang tidak stabil, sulit tidur, merokok yang berlebihan, suka menyendiri, kurang rileks, gugup dan mengalami peningkatan tekanan darah (Mangkunegara, 2011:28).Kurangnya kontrol dalam pekerjaan seseorang dikaitkan dengan tingkat stres yang tinggi. Tekanan yang mengakibatkan stres kerja dapat berasal dari tugastugas yang tidak dapat karyawan penuhi, hal ini berarti bahwa karyawan yang mengalami stres kerja diakibatkan oleh ketidakmampuan karyawan tersebut dalam memenuhi apa yang menjadi tuntutan pekerjaannya. Khalidi dan Wazalify (2013) mengungkapkan bahwa pemicu stress dapat pula berasal dari ketidakjelasan dari apa yang menjadi tanggung jawab pekerjaan, kekurangan waktu dalam penyelesaian tugas, kurangnya fasilitas yang mendukung untuk menjalankan pekerjaan dan tugas yang bertentangan. Menurut penelitian Rajak (2013) bahwa sumber utama dari tekanan bagi banyak orang jelas berasal dari konflik pekerjaan dan permintaan keluarga.Alves et al. (2004) mengidentifikasi faktor-faktor stres kerja menjadi tiga kelompok yaitu: 1) Tuntutan Pekerjaan (Demand). Tuntutan pekerjaan dapat menjadi pemicu terjadinya kelelahan secara psikologis. Tuntutan pekerjaan dapat dijelaskan seperti: bekerja dalam waktu yang terlalu lama, beban kerja yang tinggi, terbatasnya waktu yang diberikan untuk menyelesaikan suatu pekerjaan dan adanya konflik pada tuntutan pekerjaan yang harus diselesaikan.2) Kendali (Control). Kendali merupakan otoritas yang dimiliki karyawan dalam 
INOBIS: Jurnal Inovasi Bisnis dan Manajemen Indonesia

Volume 1, Nomor 3, Juni 2018

\section{Gusti Ayu Ari Warmadewi; Putu Saroyini Piartrini}

mengendalikan dan mengambil keputusan dalam pekerjaan menggunakan kemampuan yang dimiliki. 3) Dukungan Sosial (Social Support). Dukungan sosial merupakan interaksi yang terjadi ditempat kerja yaitu antara karyawan dengan rekan kerja atau dengan atasannya.Stres kerja berdampak pada timbulnya ketidakpuasan kerja karyawan (Mahfudz, 2017). Stres menjadi hambatan besar dalam efektivitas kinerja karyawan (Cahyono, 2014), mengganggu jalannya pelaksanaan pekerjaan, dapat juga merusak prestasi kerja dan mengurangi kepuasan yang dirasakan karyawan. Berdasarkan perspektif Job Demand -Control Model dan kajian empiris yang relevan dirumuskan pengaruh konflik pekerjaan -keluarga terhadap stres berikut:

H1: Konflik peran pekerjaan -keluarga berpengaruh positif terhadap stres kerja.

\subsection{Kepuasan kerja}

Teori Diskonfirmasi Ekspektasi menyatakan bahwa karyawan memiliki harapan mengenai lingtermasuk hasil yang diterima dari pekerjaaannya. Bila harapan tersebut terpenuhi maka karyawana akan memperoleh kepuasan kerja sementara bila harapan tidak terwujud maka karyawan akan merasakan ketidakpuasan. Teori dua faktor yang dikembangkan oleh Herzberg menyatakan terdapat dua faktor yang mempengaruhi kepuasan, yaitu: hygine factors dan motivation factors. Hygine factors adalah faktor pekerjaan yang penting untuk adanya motivasi di tempat kerja, hygine factors dibentuk oleh elemen-elemen: kompensasi, keamanan kerja, kondisi kerja, kebijakan perusahaan, hubungan interpersonal diantara rekan kerja, hubungan dengan atasan. Motivation factors adalah faktor-faktor yang melekat dalam pekerjaan dan memotivasi karyawan untuk sebuah kinerja yang unggul, motivation factors dibentuk olehelemen-elemen: prestasi kerja, pengakuan orang lain (rekan kerja maupun atasan), kemajuan, pekerjaan itu sendiri dan pengembangan potensi diri. Perusahaan harus memberikan perhatian kepada karyawan dengan menjamin kecukupan dari hygine factors guna menghindari ketidakpuasan karyawan dan memberikan motivator untuk peningkatan kinerja. Kepuasan kerja merupakan hal yang bersifat personal karena setiap orang akan memiliki tingkat kepuasan yang berbeda sesuai dengan karakteristik yang ada pada dirinya. Dipboye (dalam Munandar, 2012:350) memandang kepuasan kerja sebagai respon positif atau negatif terhadap berbagai aspek dari pekerjaannya. Singh dan Nayak (2015) mengungkapkan situasi pekerjaan dan sikap karyawan terhadap pekerjaannya dalam mendefinisikan kepuasan kerja.

Menurut Herzberg (dalam Ghanbahadur, 2014) terdapat sebelas aspek yang mempengaruhi kepuasan kerja yaitu 1) Prestasi kerja yaitu keberhasilan dalam menyelesaikan tugas; 2) Peluang untuk maju untuk meningkatkan dan menambah kemampuan; 3) Pekerjaan yang dibebankan kepada karyawan, bahwa pekerjaan yang dilakukan adalah penting dan berarti; 4) Pengakuan orang lain baik dari atasan maupun rekan kerja, berupa pujian maupun kenaikan gaji; 5) Peluang pengembangan potensi; 6) Kebijakan perusahaan berkaitan dengan kompensasi; 7) Hubungan dengan rekan kerja; 8) Keamanan kerja; 9) Hubungan antara bawahan dan atasan; 10) Kompensasi untuk suatu pekerjaan ataupun jasa yang telah dilakukan; 11) Kondisi kerja yang mendukung dalam menyelesaikan tugas yaitu sarana dan prasarana kerja yang memadai sesuai dengan sifat tugas yang harus diselesaikan. Terwujudnya harapan terkait lingkungan kerjanya menumbuhkan kepuasan kerja sehingga menumbuhkan suasana kerja yang nyaman, menyenangkan sehingga mendorong karyawan meningkatkan produktifitas kerjanya (Khamisa, 2017). Ketidakpuasan kerja menimbulkan keengganan bekerja, produktifitas yang rendah, pensiun dini, komitmen yang rendah, terganggunya kesehatan mental dan fisik serta karyawan, dan kecenderungan melalaikan pekerjaan (Robbins dan Judge, 2012:116). Konflik pekerjaan-keluarga berkorelasi negatif dengan kepuasan kerja (Singh dan Nayak, 2015). Berdasarkan Teori peran (Kahn et al. ,1964) mengusulkan bahwa 
INOBIS: Jurnal Inovasi Bisnis dan Manajemen Indonesia

Volume 1, Nomor 3, Juni 2018

\section{Gusti Ayu Ari Warmadewi; Putu Saroyini Piartrini}

organisasi (misalnya, pekerjaan atau keluarga) dapat dipandang sebagai sistem peran dimana hubungan antar manusia dipelihara oleh harapan yang telah dikembangkan dalam berbagai peran;

Teori job demands-control-support model (Karasek,1979) yang menjelaskan bagaimana stres kerja dapat terjadi dalam kondisi tuntutan pekerjaan yang tinggi, kontrol terhadap karyawan yang rendah, dan dukungan sosial yang rendah dan Teori Diskonfirmasi Harapan (Lankton, Nanncy \& Mc Night,Harrison, 2012). Berdasarkan kajian empiris terkait kepuasan kerja dan konflik peran pekerjaan - keluarga dirumuskan hipotesis $\mathrm{H} 2$ dan $\mathrm{H} 3$ sebagai berikut:

H2: Konflik Pekerjaan - Keluarga berpengaruh positif dengan stres kerja.

H3: Konflik Pekerjaan - Keluarga berpengaruh negatif dengan Kepuasan kerja.

Kesesuaian realita dengan harapan yang menimbulkan Kepuasan kerja maupun Ketidakpuasan kerja karyawan terhadap lingkungan kerjanya diusulkan model konseptual hubungan konflik pekerjaan-keluarga, stres kerja dan kepuasan kerja sebagai berikut:

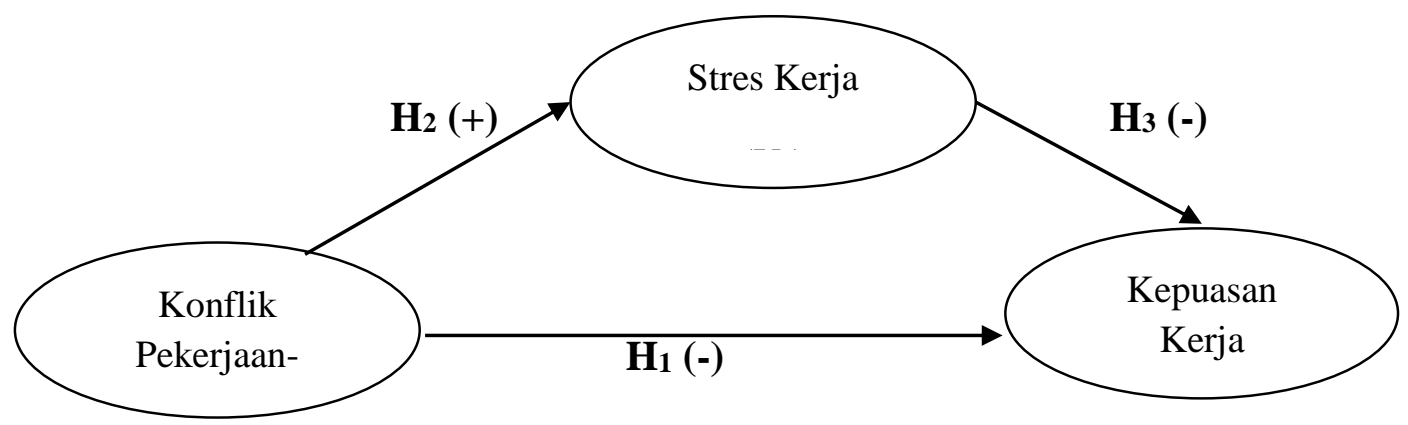

Gambar 1 Kerangka Konseptual

\section{Metode Penelitian}

Desain penelitian yang diterapkan dalam pengumpulan data penelitian adalah survei, yang melibatkan karyawan tetap CV. Bali Aquarium yang berlokasi di Jl. Muding Indah IV No 12, Kerobokan Kaja, Kuta Utara, Badung. Obyek penelitian ini adalah konflik pekerjaankeluarga, stres kerja dan kepuasan kerja karyawan CV. Bali Aquarium.

Variabel penelitian terdiri 1) Variabel bebas dalam penelitian ini adalah konflik pekerjaan-keluarga, 2)Variabel mediasi dalam penelitian ini adalah stres kerja dan 3) Variabel terikat dalam penelitian ini adalah kepuasan kerja. Definisi operasional variabel Konflik pekerjaan-keluarga adalah bentuk konflik antar-peran di mana tekanan dari pelaksanaan peran dari pekerjaan dan keluarga saling bertentangan atau terjadi pada waktu yang sama. Pengukuran konflik pekerjaan-keluarga dengan mengacu pada penelitian (Netemeyer et al. 1996) yang diukur dengan dua dimensi yaitu: Time-based conflict merupakan jumlah waktu yang dibutuhkan dalam memenuhi kebutuhan salah satu peran (keluarga atau pekerjaan) dan Strainbased conflict merupakan intensitas tekanan pelaksanaan aktivitas salah satu peran.

Stres kerja adalah persepsi karyawan terhadap tuntutan pekerjaan dibandingkan dengan persepsi kendali terhadap pekerjaan tersebut dan persepsi karyawan terhadap dukungan dari rekan kerja dan atasannya. Pengukuran stres meliputi tiga dimensi yang diacu dari penelitian Alves et al. (2004) yaitu:Tuntutan (demands) berkaitan dengan tekanan baik kuantitatif yaitu waktu dan kecepatan dalam penyelesaian tugas atau kualitatif yaitu permasalahan mengenai tuntutan pekerjaan yang tidak sesuai, kontrol (control) berhubungan dengan otoritas pekerja dalam melakukan dan menyelesaikan tugasnya dan dukungan (support) berhubungan dengan interaksi sosial antara pekerja dan atasannya. 
INOBIS: Jurnal Inovasi Bisnis dan Manajemen Indonesia

Volume 1, Nomor 3, Juni 2018

\section{Gusti Ayu Ari Warmadewi; Putu Saroyini Piartrini}

Kepuasan kerja adalah hasil penilaian antara realita terhadap elemen-elemen hygine dan elemen motivator yang dialami oleh individu di lingkungan kerja yang dihubungkan dengan ekspektasi. Dimensi lingkungan kerja yang diadopsi dari penelitian (Herzberg, 1968 dalam Ghanbahadur, 2014) yang digunakan untuk mengukur tingkat kepuasan kerja yang dirasakan para pekerja, yaitu:Prestasi kerja berkaitan dengan hasil kerja secara kualitas maupun kuantitas yang dicapai oleh seorang karyawan dalam melaksanakan tugasnya sesuai dengan tanggung jawab yang diembannya;Peluang untuk maju berkaitan dengan kesempatan untuk memperoleh posisi atau jabatan yang dapat memuaskan kehidupannya sebagai karyawan; Pekerjaan itu sendiri berkaitan dengan besar kecilnya tantangan yang dirasakan karyawan dari pekerjaannya; Pengakuan berkaitan dengan reward yang diperoleh karyawan atas apa yang telah dikerjakan dengan baik; Pengembangan potensi diri berkaitan dengan kesempatan untuk mengembangkan wawasan dan kemampuan diri karyawan; Kebijakan perusahaan berkaitan dengan kebijakan dalam prosedur kerja, keadilan dan wewenang dalam bekerja; Hubungan dengan rekan sejawat berkaitan dengan hubungan baik yang terjalin antara sesama rekan sejawat di tempat kerja; Keamanan kerja berkaitan dengan perasaan aman dan nyaman dalam menjalankan pekerjaannya; Hubungan dengan atasan berkaitan dengan hubungan yang terjalin dengan baik antara atasan dan bawahan di tempat kerja;Kompensasi berkaitan dengan imbalan yang diterima karyawan sesuai dengan tanggung jawab yang diemban; Kondisi kerja berkaitan dengan tersedianya sarana dan prasarana yang menunjang pelaksaan kerja dengan baik.

Populasi penelitian adalah seluruh karyawan di CV. Bali Aquarium yang berjumlah 50 orang. Target populasi adalah individu yang sudah berkeluarga berjumlah 39 orang. Data penelitian terdiri dari Data kuantitatif dan Data Kualitatif . data kuantitatif adalah data yang berbentuk angka atau dinyatakan dalam satuan tertentu. Data kuantitatif yang digunakan dalam penelitian ini adalahjumlah karyawan yang telah menikah dan memiliki anak yang bersumber dari HRD CV. Bali Aquarium, sementara data kualitatif adalah data yang tidak berbentuk angka atau dinyatakan dengan satuan ukuran tertentu. Data kualitatif yang digunakan dalam penelitian ini meliputi level konflik pekerjaan-keluarga, level stres kerja dengan level kepuasan kerja pada karyawan CV. Bali Aquarium.

Data penelitian dikumpulkan dari Sumber primer dan sumber sekunder. Data yang dikumpulkan dari sumber primer antara lainadalah individu karyawan CV. Bali Aquarium yang terlibat sebagai narasumber penelitian. Sedangkan data yang dikumpulkan dari sumber sekunder yaitu data jumlah karyawan yang telah menikah dan memiliki anak yang dikutip dari buku registrasi karyawan. Metode pengumpulan data adalah observasi, wawancara dan daftar pertanyaan terstruktur. Metode observasi dilakukan dengan mengamati secara langsung ke lokasi penelitian yaitu CV. Bali Aquarium, pengamatan dilakukan untuk memperoleh data presentase jumlah karyawan dan data tingkat absensi karyawan.Wawancara digunakan untuk mengumpulkan data dengan cara melakukan tanya jawab secara langsung kepada beberapa karyawan. Data yang dihasilkan pada saat melakukan wawancara dengan lima karyawan CV. Bali Aquarium berupa aspek kebijakan manajemen yang belum memuaskan dilihat dari perspektif karyawan terkait pemberian imbalan yang lebih rendah dengan kontribusi kerja, jam kerja yang padat dan tuntutan kerja yang tinggi. Metode Kuesioner merupakan teknik pengumpulan data berupa pertanyaan atau pernyataan tertulis yang didesain dengan mengacu pada instrument pengukuran data untuk mengukur level konflik pekerjaan-keluarga, dan stres kerja terhadap kepuasan kerja.

Data variabel konflik pekerjaan-keluarga diukur dengan instrument konflik pekerjaankeluarga yang dikembangkan oleh (Netemeyer et al.1996). Terdiri dari 13 butir pertanyaan untuk mengukur 2 dimensi konflik pekerjaan-keluarga. Data diukur dengan skala likert dengan interval 1 sampai 5 yang mewakili interval sangat tidak setuju hingga sangat setuju. Pernyataan 
INOBIS: Jurnal Inovasi Bisnis dan Manajemen Indonesia

Volume 1, Nomor 3, Juni 2018

\section{Gusti Ayu Ari Warmadewi; Putu Saroyini Piartrini}

dalam skala antara lain: hal-hal yang ingin saya lakukan dirumah tidak sepenuhnya dapat saya lakukan karena berbagai tuntutan pekerjaan saya di perusahaan. Data variabel stres kerja akan diukur dengan instrument stres kerja yang dikembangkan oleh Alves et al. (2004). Terdiri dari 13 butir pertanyaan untuk mengukur 3 dimensi stres kerja. Data diukur dengan skala likert dengan interval 1 sampai 5 yang mewakili interval sangat tidak setuju hingga sangat setuju. Pernyataan dalam skala antara lain: Pekerjaan mengharuskan saya bekerja dengan cepat, pekerjaan mengharuskan saya banyak belajar hal baru. Data variabel kepuasan kerja diukur dengan instrument kepuasan kerja yang dikembangkan oleh Herzberg (1968 dalam Ghanbahadur, 2014). Terdiri dari 32 butir pertanyaan untuk mengukur 11 dimensi kepuasan kerja. Data diukur dengan skala likert dengan interval 1 sampai 5 yang mewakili interval sangat tidak setuju hingga sangat setuju. Pernyataan dalam skala antara lain: pekerjaan saya menantang, saya merasa kinerja saya meningkat karena mendapat dukungan dari atasan. Uji validitas instrumen pengukuran data dilakukan dengan metode analisis product moment dengan parameter $\mathrm{r}$ minimal 0,3 dan uji reliabilitas dilakukan dengan metode skala berdasarkan parameter alpha cronbach minimal o,60.

Uji hipotesis penelitian dilakukan dengan metode Analisis jalur yang merupakan perluasan analisis regresi linier berganda dalam memperkirakan hubungan kausalitas antara yang telah ditetapkan berdasarkan teori (Ghozali, 2013:249). Teknik ini digunakan untuk menguji besarnya kontribusi yang dinyatakan oleh koefisien jalur pada setiap diagram jalur dari hubungan kausal atau sebab akibat yang tercipta dari variabel eksogen terhadap variabel endogen.

\section{Hasil Penelitian}

Hasil penelitian diperoleh sebuah gambaran mengenai karakteristik respoden CV. Bali Aquarium yang terdiri dari umur, jenis kelamin, pendidikan terakhir, masa kerja, dan jumlah anak pada Tabel 1. Responden pada penelitian di CV. Bali Aquarium dominan berusia 20 sampai 30 tahun, dengan persentase 74,36 persen., didominasi oleh jenis kelamin laki-laki dengan persentase 84,62 persen. Pekerjaan yang dilakukan cukup berat sehingga karyawan lakilaki yang lebih tepat didalam melakukan pekerjaan tersebut. Sebagian besar mengenyam pendidikan terakhir SMA/SMK yaitu sebanyak 16 orang atau persentase 41,03 persen, memiliki masa kerja 1 sampai 5 tahun 23 orang atau persentase 58,97 persen memiliki jumlah anak antara 1 sampai 3 anak yaitu 34 karyawan atau persentase sebesar 87,18 persen.

Tabel 1 Karakteristik Responden

\begin{tabular}{|c|c|c|c|c|}
\hline No & Variabel & Klasifikasi & $\begin{array}{l}\text { Jumlah } \\
\text { (orang) }\end{array}$ & $\begin{array}{c}\text { Persentase } \\
(\%)\end{array}$ \\
\hline \multirow[t]{4}{*}{1} & Umur (tahun) & $20-30$ & 29 & 74,36 \\
\hline & & $31-40$ & 5 & 12,82 \\
\hline & & $41-50$ & 5 & 12,82 \\
\hline & \multicolumn{2}{|c|}{ Jumlah } & 39 & 100 \\
\hline \multirow[t]{3}{*}{2} & \multirow[t]{2}{*}{ Jenis kelamin } & Laki-laki & 33 & 84,62 \\
\hline & & Perempuan & 6 & 15,38 \\
\hline & \multicolumn{2}{|c|}{ Jumlah } & 39 & 100 \\
\hline \multirow[t]{4}{*}{3} & \multirow[t]{4}{*}{ Pendidikan terakhir } & SMP & 9 & 23,08 \\
\hline & & SMA/SMK & 16 & 41,03 \\
\hline & & Diploma (D1) & 6 & 15,38 \\
\hline & & Sarjana & 8 & 20,51 \\
\hline
\end{tabular}


INOBIS: Jurnal Inovasi Bisnis dan Manajemen Indonesia

Volume 1, Nomor 3, Juni 2018

I Gusti Ayu Ari Warmadewi; Putu Saroyini Piartrini

\begin{tabular}{|c|c|c|c|c|}
\hline & \multicolumn{2}{|c|}{ Jumlah } & 39 & 100 \\
\hline \multirow[t]{4}{*}{4} & Masa kerja (tahun) & $1-5$ & 23 & 58,97 \\
\hline & & $6-10$ & 10 & 25,64 \\
\hline & & $11-15$ & 6 & 15,39 \\
\hline & \multicolumn{2}{|c|}{ Jumlah } & 39 & 100 \\
\hline \multirow{3}{*}{5} & Jumlah anak & $1-3$ & 34 & 87,18 \\
\hline & & $4-6$ & 5 & 12,82 \\
\hline & \multicolumn{2}{|c|}{ Jumlah } & 39 & 100 \\
\hline
\end{tabular}

Sumber:Ddata diolah

Pengujian validitas instrument penelitian dengan menggunakan metode Pearson Correlation. Instrument dapat dikatakan valid apabila Pearson Correlation terhadap skor total $\geq 0,30$. Hasil uji validitas instrument penelitian menunjukkan bahwa seluruh indikator pernyataan dalam variabel konflik pekerjaan-keluarga, stres kerja dan kepuasan kerja memiliki pearson correlation $\geq 0,30$ sehingga seluruh indikator dinyatakan valid sebagaimana disajikan pada tabel 2 berikut :

Tabel 2. Hasil Uji Validitas Instrumen

\begin{tabular}{|c|c|c|c|c|}
\hline No & Variabel & $\begin{array}{c}\text { Item } \\
\text { Pernyataan }\end{array}$ & $\begin{array}{c}\text { Pearson } \\
\text { Correlation }\end{array}$ & Keterangan \\
\hline 1 & Konflik pekerjaan- & X1 & 0,743 & Valid \\
& keluarga (X) & X2 & 0,737 & Valid \\
& & X3 & 0,843 & Valid \\
& & X4 & 0,799 & Valid \\
& & X5 & 0,810 & Valid \\
& & X6 & 0,701 & Valid \\
& & X7 & 0,693 & Valid \\
& & X8 & 0,563 & Valid \\
& & X9 & 0,667 & Valid \\
& & X10 & 0,709 & Valid \\
\hline 2 & Stres kerja (Y1) & Y1.1 & 0,670 & Valid \\
& & Y1.2 & 0,840 & Valid \\
& & Y1.3 & 0,823 & Valid \\
& & Y1.4 & 0,787 & Valid \\
& & Y1.5 & 0,586 & Valid \\
& & Y1.6 & 0,806 & Valid \\
& & Y1.7 & 0,843 & Valid \\
& & Y1.8 & 0,878 & Valid \\
& & Y1.9 & 0,793 & Valid \\
& & Y1.10 & 0,640 & Valid \\
& & Y1.11 & 0,622 & Valid \\
& & Y1.12 & 0,912 & Valid \\
& & Y1.13 & 0,877 & Valid \\
\hline
\end{tabular}


INOBIS: Jurnal Inovasi Bisnis dan Manajemen Indonesia

Volume 1, Nomor 3, Juni 2018

I Gusti Ayu Ari Warmadewi; Putu Saroyini Piartrini

\begin{tabular}{|l|c|c|c|c|}
\hline 3 & Kepuasan kerja (Y2) & Y2.1 & 0,803 & Valid \\
& & Y2.2 & 0,809 & Valid \\
& & Y2.3 & 0,823 & Valid \\
& & Y2.4 & 0,736 & Valid \\
& & Y2.5 & 0,569 & Valid \\
& & Y2.6 & 0,353 & Valid \\
& & Y2.7 & 0,359 & Valid \\
& & Y2.8 & 0,331 & Valid \\
& & Y2.9 & 0,593 & Valid \\
& & Y2.10 & 0,788 & Valid \\
& & Y2.11 & 0,818 & Valid \\
& & Y2.12 & 0,786 & Valid \\
& & Y2.13 & 0,660 & Valid \\
\hline
\end{tabular}

Sumber: Data diolah.

Uji reabilitas bertujuan untuk mengetahui sejauh mana alat ukur dapat dipercaya atau dapat diandalkan. Pengujian reabilitas dilakukan terhadap instrument dengan koefisien cronbach's alpha. Apabila nilai cronbach's alpha lebih besar dari 0,60 maka instrument yang digunakan realibel. Hasil uji reabilitas instrument pada penelitian ini disajikan pada Tabel 3 yang menunjukkan bahwa ketiga instrument penelitian yaitu konflik pekerjaan-keluarga, stres kerja dan kepuasan kerja memiliki koefisien cronbach's alpha yang lebih besar dari angka 0,60 sehingga pernyataan pada kuesioner tersebut dapat dikatakan realibel.

Tabel 3. Hasil Uji Reabilitas Instrumen

\begin{tabular}{|cl|c|c|}
\hline No & \multicolumn{1}{|c|}{ Variabel } & Cronbach's Alpha & Keterangan \\
\hline 1 & Konflik pekerjaan-keluarga & 0,902 & Realibel \\
2 & Stres kerja & 0,946 & Realibel \\
3 & Kepuasan kerja & 0,948 & Realibel \\
\hline
\end{tabular}

Sumber: Data diolah

Deskripsi skor variabel konflik pekerjaan-keluarga yang diukur dengan menggunakan 10 butir pertanyaan disajikan pada Tabel 4. Rata-rata persepsi responden mengenai konflik pekerjaan-keluarga secara keseluruhan sebesar 4,08 sehingga persepsi konflik pekerjaan keluarga dikategorikan pada level tinggi. Rincian deskripsi skor variabel stres kerja disajikan pada tabel 4. 
INOBIS: Jurnal Inovasi Bisnis dan Manajemen Indonesia

Volume 1, Nomor 3, Juni 2018

I Gusti Ayu Ari Warmadewi; Putu Saroyini Piartrini

Tabel 4. Deskripsi Persepsi Responden terhadap Konflik Pekerjaan-Keluarga

\begin{tabular}{|c|c|c|c|c|c|}
\hline No & Pernyataan & $\begin{array}{l}\text { Rata- } \\
\text { Rata }\end{array}$ & $\begin{array}{c}\text { Std } \\
\text { Deviasi }\end{array}$ & $\begin{array}{c}\text { Value } \\
\text { Responden }\end{array}$ & Interpretasi \\
\hline 1 & $\begin{array}{l}\text { Berbagai tuntutan pekerjaan saya mengganggu } \\
\text { kehidupan pribadi saya (Keluarga atau waktu } \\
\text { senggang saya). }\end{array}$ & 4,28 & 0,724 & $\begin{array}{l}\text { Sangat } \\
\text { setuju }\end{array}$ & $\begin{array}{l}\text { Sangat } \\
\text { Tinggi }\end{array}$ \\
\hline 2 & $\begin{array}{l}\text { Jumlah waktu yang dihabiskan untuk } \\
\text { menyelesaikan pekerjaan membuat sulit untuk } \\
\text { memenuhi tanggung jawab keluarga. }\end{array}$ & 3,79 & 0,978 & Setuju & Tinggi \\
\hline 3 & $\begin{array}{l}\text { Hal-hal yang ingin saya lakukan di rumah } \\
\text { tidak sepenuhnya dapat saya lakukan karena } \\
\text { berbagai tuntutan pekerjaan saya. }\end{array}$ & 3,92 & 0,957 & Setuju & Tinggi \\
\hline 4 & $\begin{array}{l}\text { Pekerjaan saya menimbulkan tekanan yang } \\
\text { menyulitkan saya untuk memenuhi berbagai } \\
\text { tugas dalam keluarga }\end{array}$ & 4,21 & 0,801 & Setuju & Tinggi \\
\hline 5 & $\begin{array}{l}\text { Dengan adanya kewajiban yang berkaitan } \\
\text { dengan pekerjaan, saya kadang harus membuat } \\
\text { berbagai perubahan terhadap rencana-rencana } \\
\text { saya tentang berbagai aktivitas keluarga. }\end{array}$ & 4,21 & 0,695 & Setuju & Tinggi \\
\hline 6 & $\begin{array}{lcc}\text { Berbagai tuntutan dari keluarga } & \text { saya } \\
\text { mengganggu berbagai aktifitas } & \text { yang } \\
\text { berhubungan dengan pekerjaan saya. } & \end{array}$ & 4,13 & 0,801 & Setuju & Tinggi \\
\hline 7 & $\begin{array}{l}\text { Saya mengesampingkan berbagai hal yang } \\
\text { sedang saya kerjakan di perusahaan karena } \\
\text { berbagai tuntutan waktu saya di rumah. }\end{array}$ & 4,05 & 0,916 & Setuju & Tinggi \\
\hline 8 & $\begin{array}{l}\text { Hal-hal yang ingin saya lakukan di tempat } \\
\text { kerja tidak sepenuhnya dapat saya lakukan } \\
\text { karena berbagai tuntutan keluarga saya. }\end{array}$ & 4,21 & 0,570 & Setuju & Tinggi \\
\hline 9 & $\begin{array}{l}\text { Kehidupan pribadi saya mengganggu } \\
\text { tanggung jawab saya di tempat kerja seperti } \\
\text { bekerja tepat waktu. }\end{array}$ & 4,15 & 0,961 & Setuju & Tinggi \\
\hline \multirow[t]{2}{*}{10} & $\begin{array}{l}\text { Tekanan yang berhubungan dengan keluarga } \\
\text { mengganggu kemampuan saya untuk } \\
\text { melaksanakan tugas yang berhubungan } \\
\text { dengan pekerjaan. }\end{array}$ & 3,90 & 0,852 & Setuju & Tinggi \\
\hline & $\begin{array}{l}\text { Total Rata-Rata Skor Konflik Pekerjaan- } \\
\text { Keluarga }\end{array}$ & 4,08 & & & Tinggi \\
\hline
\end{tabular}

Sumber: data diolah

Rata-rata persepsi responden mengenai variabel stres kerja secara keseluruhan adalah sebesar 4,21 sehingga dikategorikan stres kerja karyawan tinggi. Berdasarkan hasil deskripsi persepsi responden terhadap variabel stres kerja yang diukur dengan 13 indikator menunjukkan nilai rata-rata tertinggi pada pernyataan nomor 11 yakni "saya harus mampu menentukan waktu kerja sendiri" dengan nilai sebesar 4,41. Hasil tersebut mengindikasikan bahwa tuntutan kemandirian dalam bekerja menjadi pemicu stres kerja yang paling kuat. 
INOBIS: Jurnal Inovasi Bisnis dan Manajemen Indonesia

Volume 1, Nomor 3, Juni 2018

I Gusti Ayu Ari Warmadewi; Putu Saroyini Piartrini

Tabel 5. Deskripsi Persepsi Responden terhadap Stres Kerja

\begin{tabular}{|c|c|c|c|c|c|}
\hline No & Pernyataan & $\begin{array}{l}\text { Rata- } \\
\text { Rata }\end{array}$ & $\begin{array}{c}\text { Std } \\
\text { Deviasi }\end{array}$ & $\begin{array}{c}\text { Value } \\
\text { Responden }\end{array}$ & Interpretasi \\
\hline 1 & $\begin{array}{l}\text { Pekerjaan mengharuskan saya bekerja } \\
\text { dengan cepat }\end{array}$ & 4,15 & 0,812 & Setuju & Tinggi \\
\hline 2 & Pekerjaan saya sangat padat & 4,18 & 0,885 & Setuju & Tinggi \\
\hline 3 & Pekerjaan saya memerlukan banyak tenaga & 4,36 & 0,743 & $\begin{array}{l}\text { Sangat } \\
\text { setuju }\end{array}$ & Sangat tinggi \\
\hline 4 & $\begin{array}{l}\text { Pekerjaan membuat tidak memberikan } \\
\text { cukup waktu istirahat }\end{array}$ & 4,21 & 0,801 & Setuju & Tinggi \\
\hline 5 & $\begin{array}{l}\text { Pekerjaan saya membuat pekerjaan lain } \\
\text { tidak dapat terselesaikan }\end{array}$ & 4,26 & 0,595 & $\begin{array}{l}\text { Sangat } \\
\text { setuju }\end{array}$ & Sangat tinggi \\
\hline 6 & $\begin{array}{l}\text { Pekerjaan saya mengharuskan saya banyak } \\
\text { belajar hal baru }\end{array}$ & 4,05 & 0,793 & Setuju & Tinggi \\
\hline 7 & $\begin{array}{l}\text { Pekerjaan saya menuntut keterampilan } \\
\text { yang tinggi }\end{array}$ & 4,08 & 1,010 & Setuju & Tinggi \\
\hline 8 & $\begin{array}{l}\text { Pekerjaan saya mengharuskan saya } \\
\text { menerapkan teknologi baru }\end{array}$ & 4,08 & 0,929 & Setuju & Tinggi \\
\hline 9 & $\begin{array}{l}\text { Pekerjaan saya membuat pekerjaan lain } \\
\text { tidak dapat terselesaikan }\end{array}$ & 4,33 & 0,737 & $\begin{array}{l}\text { Sangat } \\
\text { setuju }\end{array}$ & Tinggi \\
\hline 10 & Saya harus mengambil insiatif saat bekerja & 4,28 & 0,647 & $\begin{array}{l}\text { Sangat } \\
\text { setuju }\end{array}$ & Sangat tinggi \\
\hline 11 & $\begin{array}{l}\text { Saya harus mampu menentukan waktu } \\
\text { kerja sendiri }\end{array}$ & 4,41 & 0,498 & $\begin{array}{l}\text { Sangat } \\
\text { setuju }\end{array}$ & Sangat tinggi \\
\hline 12 & $\begin{array}{l}\text { Saya harus mampu menentukan metode } \\
\text { kerja secara mandiri }\end{array}$ & 4,23 & 0,902 & Setuju & Tinggi \\
\hline \multirow[t]{2}{*}{13} & Suasana ditempat kerja kurang tenang & 4,18 & 0,885 & Setuju & Tinggi \\
\hline & Total Rata-Rata Skor Stres Kerja & 4,21 & & & Tinggi \\
\hline
\end{tabular}

Sumber: Data diolah

Skor rata-rata variabel kepuasan kerja yang diukur dengan 32 butir pertanyaan . Rincian deskripsi skor variabel kepuasan kerja secara rinci disajikan pada Tabel 5. Rata-rata persepsi responden mengenai variabel kepuasan kerja secara keseluruhan adalah sebesar 3,06 yang dapat dikategorikan belum mencapai kepuasan maksimal yaitu cukup puas.

Pengujian hipotesis menggunakan analisis jalur (path analysis). Perhitungan koefisien jalur dilakukan dengan analisis regresi melalui software SPSS Statistics 20.0 for Windows memperoleh hasil yang ditunjukkan pada Tabel 6 dan Tabel 7sebagai berikut:

Pengujian hipotesis penelitian ditunjukkan oleh persamaan regresi 1 yang menjelaskan bahwa variabel konflik pekerjaan-keluarga berpengaruh nyata terhadap stres kerja Koefisien regresi konflik pekerjaan-keluarga sebesar 0,379 memiliki arti bahwa apabila faktor konflik pekerjaan-keluarga meningkat maka akan mengakibatkan meningkatnya stres kerja karyawan CV. Bali Aquarium sebesar 0,379. 
INOBIS: Jurnal Inovasi Bisnis dan Manajemen Indonesia

Volume 1, Nomor 3, Juni 2018

I Gusti Ayu Ari Warmadewi; Putu Saroyini Piartrini

Tabel 5. Deskripsi Persepsi Responden terhadap Kepuasan Kerja

\begin{tabular}{|c|c|c|c|c|c|}
\hline No & Pernyataan & $\begin{array}{l}\text { Rata- } \\
\text { Rata }\end{array}$ & $\begin{array}{c}\text { Std } \\
\text { Deviasi }\end{array}$ & $\begin{array}{c}\text { Value } \\
\text { Responden }\end{array}$ & $\begin{array}{l}\text { Inter } \\
\text { pretasi }\end{array}$ \\
\hline 1 & $\begin{array}{l}\text { Saya bangga bekerja di perusahaan ini karena } \\
\text { prestasi kerja saya diakui }\end{array}$ & 2,38 & 1,184 & Tidak setuju & $\begin{array}{l}\text { Tidak } \\
\text { puas }\end{array}$ \\
\hline 2 & $\begin{array}{l}\text { Saya merasa puas dengan pekerjaan saya } \\
\text { karena membuat saya berprestasi }\end{array}$ & 2,13 & 1,196 & Tidak setuju & $\begin{array}{l}\text { Tidak } \\
\text { puas }\end{array}$ \\
\hline 3 & $\begin{array}{l}\text { Saya merasa telah memberikan kontirbusi } \\
\text { kepada perusahaan dengan prestasi yang baik }\end{array}$ & 2,46 & 1,335 & Tidak setuju & $\begin{array}{l}\text { Tidak } \\
\text { puas }\end{array}$ \\
\hline 4 & $\begin{array}{l}\text { Saya akan memilih pengembangan karir saya } \\
\text { dibandingkan dengan insentif uang }\end{array}$ & 2,92 & 1,265 & Netral & Cukup \\
\hline 5 & $\begin{array}{l}\text { Pekerjaan saya saat ini memungkinkan saya } \\
\text { untuk mempelajari keterampilan baru demi } \\
\text { kemajuan karir di masa depan }\end{array}$ & 3,36 & 1,088 & Netral & Cukup \\
\hline 6 & Pekerjaan saya menantang & 3,77 & 1,012 & Setuju & Puas \\
\hline 7 & $\begin{array}{l}\text { Pekerjaan saya memiliki banyak variasi tugas } \\
\text { yang harus dilakukan }\end{array}$ & 3,92 & 1,109 & Setuju & Puas \\
\hline 8 & $\begin{array}{l}\text { Saya merasa diberikan keleluasaan untuk } \\
\text { melakukan pekerjaan saya }\end{array}$ & 3,10 & 1,095 & Netral & Cukup \\
\hline 9 & Pekerjaan saya menarik & 2,41 & 1,186 & Tidak setuju & $\begin{array}{l}\text { Tidak } \\
\text { puas }\end{array}$ \\
\hline 10 & $\begin{array}{l}\text { Saya merasa dihargai ketika saya berhasil } \\
\text { menyelesaikan tugas dengan baik }\end{array}$ & 2,85 & 1,040 & Netral & Cukup \\
\hline 11 & $\begin{array}{l}\text { Atasan saya selalu berterima kasih terhadap } \\
\text { pekerjaan yang telah diselesaikan dengan baik }\end{array}$ & 2,79 & 1,128 & Netral & Cukup \\
\hline 12 & $\begin{array}{l}\text { Saya mendapatkan cukup pengakuan saat } \\
\text { melakukan pekerjaan dengan baik }\end{array}$ & 2,74 & 1,044 & Netral & Cukup \\
\hline 13 & $\begin{array}{l}\text { Saya bangga bekerja di perusahaan ini karena } \\
\text { saya merasa telah berkembang menjadi seorang } \\
\text { individu }\end{array}$ & 2,59 & 1,292 & Tidak setuju & $\begin{array}{l}\text { Tidak } \\
\text { puas }\end{array}$ \\
\hline 14 & $\begin{array}{l}\text { Pekerjaan saya memungkinkan saya untuk } \\
\text { berkembang }\end{array}$ & 3,28 & 1,050 & Netral & Cukup \\
\hline 15 & $\begin{array}{l}\text { Pekerjaan saya memungkinkan saya untuk } \\
\text { meningkatkan keterampilan }\end{array}$ & 3,36 & 1,063 & Netral & Cukup \\
\hline 16 & $\begin{array}{l}\text { Pengambilan kebijakan sangat membantu } \\
\text { dalam perusahaan saya }\end{array}$ & 2,69 & 1,055 & Netral & Cukup \\
\hline 17 & $\begin{array}{l}\text { Saya bangga bekerja di perusahaan ini karena } \\
\text { kebijakan perusahaan membantu pekerja }\end{array}$ & 2,59 & 1,069 & Tidak setuju & $\begin{array}{l}\text { Tidak } \\
\text { puas }\end{array}$ \\
\hline 18 & $\begin{array}{l}\text { Saya mengerti sepenuhnya dengan misi } \\
\text { perusahaan }\end{array}$ & 3,31 & 0,800 & Netral & Cukup \\
\hline 19 & $\begin{array}{l}\text { Saya sangat mudah bergaul dengan rekan } \\
\text { sejawat }\end{array}$ & 3,74 & 0,785 & Setuju & Puas \\
\hline 20 & Rekan saya sangat membantu & 3,51 & 0,885 & Setuju & Puas \\
\hline 21 & Rekan saya sangat bersahabat & 3,21 & 1,105 & Netral & Cukup \\
\hline 22 & Rekan sejawat sangat penting bagi saya & 2,69 & 1,280 & Netral & Cukup \\
\hline 23 & Saya merasa aman bekerja di tempat kerja & 3,56 & 1,021 & Setuju & Puas \\
\hline
\end{tabular}


INOBIS: Jurnal Inovasi Bisnis dan Manajemen Indonesia

Volume 1, Nomor 3, Juni 2018

I Gusti Ayu Ari Warmadewi; Putu Saroyini Piartrini

\begin{tabular}{|c|c|c|c|c|c|}
\hline 24 & Saya percaya pekerjaan saya saat ini aman & 3,08 & 1,133 & Netral & Cukup \\
\hline 25 & $\begin{array}{l}\text { Tempat kerja saya berlokasi di area yang } \\
\text { nyaman }\end{array}$ & 3,64 & 0,811 & Setuju & Puas \\
\hline 26 & $\begin{array}{l}\text { Saya merasa kinerja saya meningkat karena } \\
\text { mendapat dukungan dari atasan }\end{array}$ & 3,36 & 0,707 & Netral & Cukup \\
\hline 27 & $\begin{array}{l}\text { Saya merasa puas di tempat kerja karena } \\
\text { hubungan baik saya dengan atasan }\end{array}$ & 3,08 & 0,900 & Netral & Cukup \\
\hline 28 & Atasan saya pemimpin yang dapat dipercaya & 3,36 & 0,743 & Netral & Cukup \\
\hline 29 & $\begin{array}{l}\text { Saya di dorong untuk bekerja lebih giat karena } \\
\text { gaji yang saya terima }\end{array}$ & 3,26 & 1,044 & Netral & Cukup \\
\hline 30 & Saya percaya gaji yang saya terima sudah adil & 3,05 & 1,050 & Netral & Cukup \\
\hline 31 & $\begin{array}{l}\text { Saya merasa puas karena kenyamanan di } \\
\text { tempat kerja }\end{array}$ & 2,95 & 1,075 & Netral & Cukup \\
\hline \multirow[t]{2}{*}{32} & $\begin{array}{l}\text { Saya bangga bekerja di perusahaan ini karena } \\
\text { kondisi kerja yang menyenangkan }\end{array}$ & 2,90 & 1,071 & Netral & Cukup \\
\hline & Total Rata-Rata Skor Kepuasan Kerja & 3,06 & & & Cukup \\
\hline
\end{tabular}

Sumber: data diolah

Hasil analisis jalur substruktural 1 yang disajikan pada Tabel 7 maka persamaan stukturalnya yaitu:

$$
\begin{array}{ll}
\mathrm{Y}_{1} & =\beta_{2} \mathrm{X}+\mathrm{e}_{1} \\
\mathrm{Y}_{1} & =0,379 \mathrm{X}+\mathrm{e}_{1}
\end{array}
$$

Tabel 6. Hasil Analisis Jalur Persamaan Regresi 1

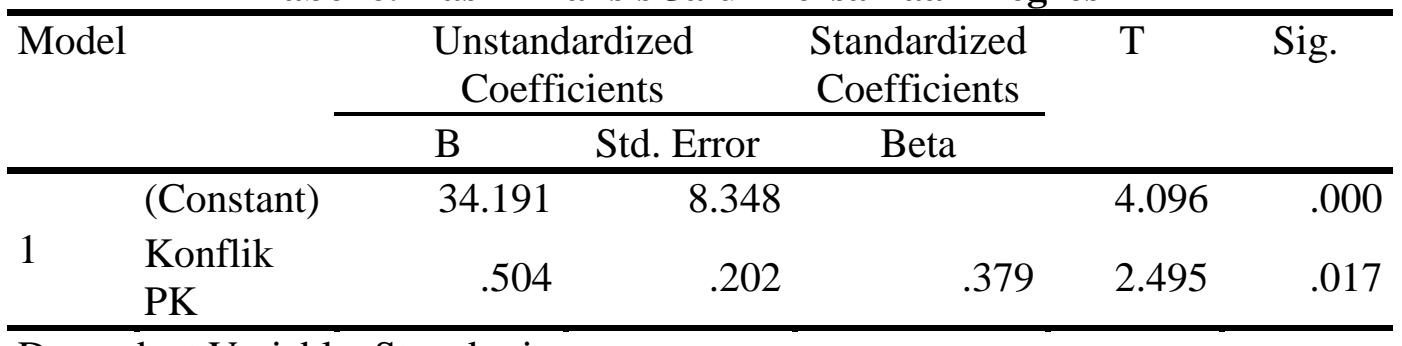

Dependent Variable: Stres kerja

\begin{tabular}{|c|c|c|c|c|c|c|}
\hline \multirow{2}{*}{\multicolumn{2}{|c|}{ Model }} & \multicolumn{2}{|c|}{$\begin{array}{l}\text { Unstandardized } \\
\text { Coefficients }\end{array}$} & \multirow{2}{*}{$\begin{array}{c}\text { Standardized } \\
\text { Coefficients } \\
\text { Beta }\end{array}$} & \multirow[t]{2}{*}{$\mathrm{T}$} & \multirow[t]{2}{*}{ Sig. } \\
\hline & & $\mathrm{B}$ & Std. Error & & & \\
\hline \multirow{3}{*}{1} & (Constant) & 75.932 & 3.224 & & 1.840 & .075 \\
\hline & Konfik PK & -.296 & .103 & -.383 & -2.872 & .007 \\
\hline & Stres & -.392 & .073 & -.342 & -2.606 & .014 \\
\hline
\end{tabular}

Tabel 7.Hasil Analisis Jalur Persamaan Regresi 2

Dependent Variable: Kepuasan kerja

Berdasarkan persamaan regresi 2 yang ditampilkan diatas dapat dijelaskan bahwa variabel konflik pekerjaan-keluarga dan stres kerja berpengaruh nyata terhadap kepuasan kerja. Koefisien regresi konflik pekerjaan-keluarga sebesar -0,383 memiliki arti bahwa apabila faktor konflik pekerjaan-keluarga meningkat maka akan mengakibatkan menurunnya kepuasan kerja karyawan CV. Bali Aquarium sebesar -0,383. Koefisien regresi stres kerja sebesar $-0,342$ 
INOBIS: Jurnal Inovasi Bisnis dan Manajemen Indonesia

Volume 1, Nomor 3, Juni 2018

\section{Gusti Ayu Ari Warmadewi; Putu Saroyini Piartrini}

memiliki arti bahwa apabila faktor stres kerja meningkat maka akan mengakibatkan menurunnya kepuasan kerja karyawan di CV. Bali Aquarium sebesar -0,342. Sebelum menyusun model analisis jalur dihitung nilai standar error sebagai berikut:

Tabel 8. Hasil Pengujian Nilai Standar Eror

\begin{tabular}{|c|c|c|}
\hline Hasil Pengujian & Nilai Standar Error & Keterangan \\
\hline $\mathrm{Pe}_{1}$ & 0,925 & Standar eror variabel stres kerja $\mathrm{e}_{1}$ \\
\hline $\mathrm{Pe}_{2}$ & 0,766 & $\begin{array}{c}\text { Standar eror variabel kepuasan kerja } \\
\mathrm{e}_{2}\end{array}$ \\
\hline
\end{tabular}

Sumber: Data diolah

Jika disajikan ke dalam bentuk diagram koefisien jalur, maka tampak pada gambar 2 sebagai berikut:

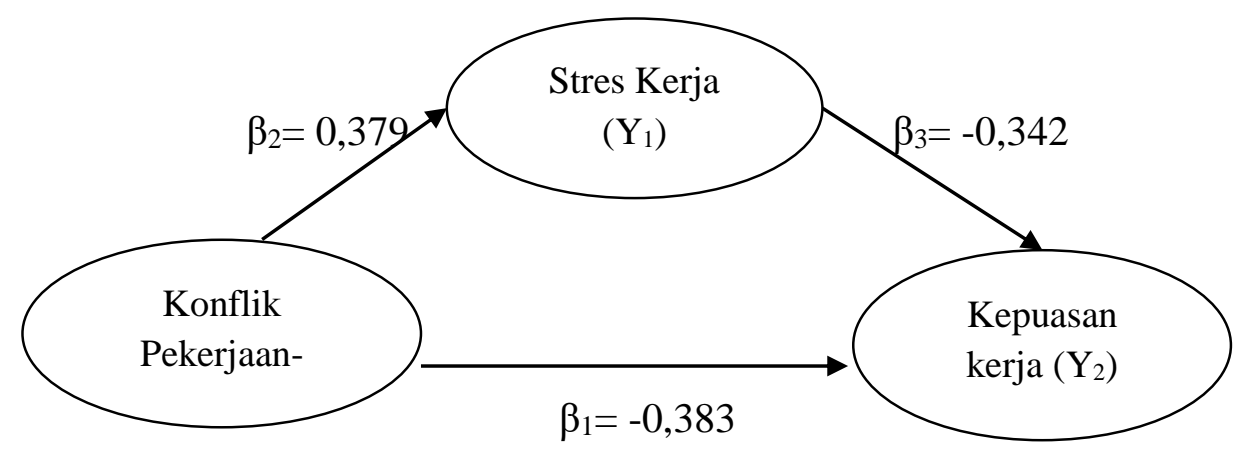

Gambar 2. Diagram Koefisien Jalur

Berdasarkan diagram koefisien jalur, secara rinci dapat dihitung besarnya pengaruh langsung dan pengaruh tidak langsung serta pengaruh total antar variabel. Perhitungan pengaruh antar variabel adalah : Pengaruh langsung (direct effect):a) Pengaruh variabel konflik pekerjaan-keluarga $(\mathrm{X})$ terhadap kepuasan kerja $\left(\mathrm{Y}_{2}\right)$ sebesar $\left.\beta_{1}=-0,383 ; \mathrm{b}\right)$ Pengaruh variabel konflik pekerjaan-keluarga $(\mathrm{X})$ terhadap stres kerja $\left(\mathrm{Y}_{1}\right)$ sebesar $\beta_{2}=0,379$; c) Pengaruh variabel stres kerja $\left(\mathrm{Y}_{1}\right)$ terhadap kepuasan kerja $\left(\mathrm{Y}_{2}\right)$ sebesar $\beta_{3}=-0,342$. Pengaruh tidak langsung (indirect effect):Pengaruh variabel konflik pekerjaan-keluarga (X) terhadap kepuasan kerja $\left(\mathrm{Y}_{2}\right)$ dengan stres kerja sebagai variabel mediasi $\left(\mathrm{Y}_{1}\right)$ :

$$
\begin{aligned}
\text { Indirect effect } & =\beta_{2} \times \beta_{3} \\
& =0,379 \times-0,342=-0,129
\end{aligned}
$$

Total pengaruh variabel konflik pekerjaan-keluarga terhadap kepuasan kerja melalui stres kerja sebagai berikut:

$$
\begin{aligned}
\text { Total effect } & =\beta_{1}+\left(\beta_{2}\right) \times\left(\beta_{3}\right) \\
& =-0,383+(0,379) \times(-0,342) \\
& =-0,512
\end{aligned}
$$

Berdasarkan perhitungan nilai standar eror, didapatkan hasil $\mathrm{Pe}_{1}$ atau standar eror variabel stres kerja sebesar 0,925 dan $\mathrm{Pe}_{2}$ atau standar eror variabel kepuasan kerja sebesar 0,766. Nilai determinasi total sebesar 0,499 memiliki arti bahwa sebesar 49,9\% variasi kepuasan kerja dipengaruhi oleh variasi konflik pekerjaan-keluarga dan stres kerja, sedangkan 
INOBIS: Jurnal Inovasi Bisnis dan Manajemen Indonesia

Volume 1, Nomor 3, Juni 2018

\section{Gusti Ayu Ari Warmadewi; Putu Saroyini Piartrini}

sisanya sebesar 50,1\% dijelaskan oleh faktor lain yang tidak dimasukkan ke dalam model penelitian. Hasil analisis pengaruh konflik pekerjaan-keluarga terhadap kepuasan kerja diperoleh hasil nilai Sig. $\mathrm{t}=0,007$. Nilai Sig. $\mathrm{t}=0,007<0,05$ mengindikasikan bahwa $\mathrm{H}_{0}$ ditolak dan $\mathrm{H}_{1}$ diterima yang berarti terdapat pengaruh yang signifikan antara konflik pekerjaankeluarga terhadap kepuasan kerja. Nilai koefisien beta sebesar -0,383, menunjukkan arah negatif. Hal tersebut mengungkapkan bahwa konflik pekerjaan-keluarga berpengaruh negatif terhadap kepuasan kerja. Ketika konflik pekerjaan-keluarga meningkat maka kepuasan kerja akan mengalami penurunan. Berdasarkan perhitungan tersebut, membuktikan bahwa hipotesis pertama yang diajukan dalam penelitian ini yaitu "konflik pekerjaan-keluarga berpengaruh negatif dan signifikan terhadap kepuasan kerja karyawan CV. Bali Aquarium”. Hasil analisis pengaruh konflik pekerjaan-keluarga terhadap stres kerjamenunjukkan hasil nilai Sig. $\mathrm{t}=$ 0,017. Nilai Sig. $\mathrm{t}=0,017<0,05$ mengindikasikan bahwa $\mathrm{H}_{0}$ ditolak dan $\mathrm{H}_{1}$ diterima yang berarti terdapat pengaruh yang signifikan antara konflik pekerjaan-keluarga terhadap stres kerja. Nilai koefisien beta sebesar 0,379, menunjukkan arah positif. Hal tersebut mengungkapkan bahwa konflik pekerjaan-keluarga berpengaruh positif terhadap kepuasan kerja. Ketika konflik pekerjaan-keluarga meningkat maka stres kerja juga akan mengalami peningkatan. Berdasarkan perhitungan tersebut, membuktikan bahwa hipotesis kedua yang diajukan dalam penelitian ini yaitu "konflik pekerjaan-keluarga berpengaruh positif dan signifikan terhadap stres kerja karyawan CV. Bali Aquarium". Analisis pengaruh stres kerja terhadap kepuasan kerja, diperoleh hasil nilai Sig. $t$ sebesar 0,014. Nilai Sig. $t=0,014<0,05$ mengindikasikan bahwa $\mathrm{H}_{0}$ ditolak dan $\mathrm{H}_{1}$ diterima yang berarti terdapat pengaruh yang signifikan antara stres kerja terhadap kepuasan kerja. Nilai koefisien beta sebesar $-0,342$, menunjukkan arah negatif. Hal tersebut mengungkapkan bahwa stres kerja berpengaruh negatif terhadap kepuasan kerja. Ketika stres kerja meningkat maka kepuasan kerja akan mengalami penurunan. Berdasarkan perhitungan tersebut, membuktikan bahwa hipotesis ketiga yang diajukan dalam penelitian ini yaitu "stres kerja berpengaruh negatif dan signifikan terhadap kepuasan kerja karyawan CV. Bali Aquarium".

Berdasarkan hasil persamaan menghasilkan $\mathrm{F}$ hitung sebesar 6,224 dengan tingkat signifikansi 0,017 dibawah 0,05. Dengan koefisien signifikan $\leq 0,05$ hal ini berarti bahwa variabel konflik pekerjaan-keluarga secara simultan berpengaruh terhadap stres kerja. Kesimpulannya adalah bahwa model persamaan struktural telah memenuhi syarat Goodness of Fit melalui uji F. Hasil ini memberikan makna bahwa variabel konflik pekerjaan-keluarga mampu memprediksi atau menjelaskan variabel stres kerja pada karyawan CV. Bali Aquarium. Berdasarkan hasil persamaan regresi yang menghasilkan $F$ hitung sebesar 10,442 dengan tingkat signifikansi 0,000 jauh dibawah 0,05. Dengan koefisien signifikan $\leq 0,05$ hal ini berarti bahwa variabel konflik pekerjaan-keluarga dan stres kerja secara simultan berpengaruh terhadap kepuasan kerja. Kesimpulannya adalah bahwa model persamaan struktural telah memenuhi syarat Goodness of Fit melalui uji F. Hasil ini memberikan makna bahwa variabel konflik pekerjaan-keluarga dan stres kerja mampu memprediksi atau menjelaskan variabel kepuasan kerja pada karyawan CV. Bali Aquarium.Hasil analisis menunjukkan bahwa pengaruh langsung variabel konflik pekerjaan-keluarga terhadap kepuasan kerja memiliki nilai koefisien beta sebesar $-0,383$, namun pengaruh tidak langsung yang dimediasi oleh stres kerja menunjukkan nilai koefisien beta sebesar -0,129. Ini membuktikan bahwa stres kerja memediasi pengaruh konflik pekerjaan-keluarga terhadap kepuasan kerja dengan pengaruh total yang diperoleh adalah sebesar $-0,512$.

Uji sobel dilakukan dengan cara menguji kekuatan pengaruh tidak langsung variabel bebas $(\mathrm{X})$ ke variabel terikat (Y) melalui variabel mediasi (M). Menguji signifikansi pengaruh tidak langsung stres kerja dengan konflik pekerjaan-keluarga dan kepuasan kerja, maka nilai $\mathrm{t}$ 
INOBIS: Jurnal Inovasi Bisnis dan Manajemen Indonesia

Volume 1, Nomor 3, Juni 2018

\section{Gusti Ayu Ari Warmadewi; Putu Saroyini Piartrini}

dari koefisien ab dihitung dengan rumus sebagai berikut: Berdasarkan perhitungan diperoleh nilai t hitung sebesar 2,231. Nilai t hitung sebesar 2,231 lebih besar dari 1,96. Jika nilai kalkulasi t hitung lebih besar dari t tabel sebesar 1,96 maka variabel mediator stres kerja termasuk ke dalam mediasi parsial karena dinilai secara signifikan memediasi hubungan antara konflik pekerjaan-keluarga terhadap kepuasan kerja karyawan.

\section{Kesimpulan.}

Hasil analisis data menunjukkan bahwa konflik pekerjaan-keluarga yang dialami karyawan dapat menurunkan kepuasan kerja karyawan, sehingga karyawan yang merasakan konflik pekerjaan-keluarga yang tinggi, maka akan menurunkan kepuasan kerja karyawan tersebut. Sebaliknya semakin rendah konflik yang dialami karyawan maka akan meningkatkan kepuasan kerja karyawan di CV. Bali Aquarium. Hasil penelitian ini didukung oleh hasil dari penelitian sebelumnya yang dilakukan oleh Singh dan Nayak (2015) menemukan bahwa adanya pengaruh yang negatif dan signifikan dari konflik pekerjaan-keluarga terhadap kepuasan kerja. Gao et al. (2013) menemukan bahwa konflik pekerjaan-keluarga menghasilkan tekanan psikologis yang lebih besar dan menurunkan kepuasan kerja secara signifikan. Hasil penelitian dari Anafarta (2011) menunjukkan konflik pekerjaan-keluarga memiliki efek negatif pada kepuasan kerja, dimana fakta bahwa karyawan menyadari konflik pekerjaan-keluarga yang mereka alami efektif mengurangi kepuasan kerja. Konflik pekerjaan-keluarga yang dialami karyawan dapat meningkatkan stres kerja karyawan, sehingga semakin tinggi konflik pekerjaan-keluarga, maka semakin tinggi pula stres kerja dari karyawan CV. Bali Aquarium. Hasil ini mendukung hasil penelitian sebelumnya yang dilakukan oleh Jamadin et al. (2014) menemukan bahwa konflik-pekerjaan keluarga berpengaruh positif terhadap terjadinya stres kerja. Menurut Khamisa et al. (2015) konflik kerja dan konflik keluarga secara bersamaan dapat menganggu atau mempengaruhi secara positif stres kerja. Penelitian oleh Singh dan Nayak (2015) menemukan hasil bahwa konflik pekerjaan-keluarga berpengaruh positif terhadap stres kerja. Stres kerja yang dialami karyawan dapat menurunkan kepuasan kerja karyawan, sehingga karyawan yang merasakan stres kerja yang tinggi, maka akan menurunkan kepuasan kerja karyawan tersebut. Sebaliknya semakin rendah stres yang dialami karyawan maka akan meningkatkan kepuasan kerja karyawan di CV. Bali Aquarium. Hasil penelitian ini didukung oleh hasil penelitian sebelumnya yang menemukan bahwa stres kerja memiliki pengaruh negatif terhadap kepuasan kerja (Khalidi dan Wazalify, 2013). Menurut Iqbal dan Waseem (2012) stres kerja merupakan masalah serius yang berhubungan dengan kepuasan kerja, hal ini dibuktikan dengan penelitian yang telah dilakukan memperoleh hasil bahwa stres kerja berpengaruh negatif terhadap kepuasan kerja. Penelitian yang dilakukan oleh Singh dan Nayak (2015) terhadap polisi di India menemukan bahwa stres kerja berpengaruh secara signifikan terhadap kepuasan kerja.

Berdasarkan hasil dari penelitian ini menunjukkan bahwa konflik pekerjaan-keluarga berpengaruh negatif terhadap kepuasan kerja, konflik pekerjaan-keluarga berpengaruh positif terhadap stres kerja, stres kerja berpengaruh negatif terhadap kepuasan kerja dan stres kerja memediasi antara konflik pekerjaan-keluarga dengan kepuasan kerja karyawan CV. Bali Aquarium. Pihak pengelola manajemen CV. Bali Aquarium, disarankan untuk menyesuaikan kapasitas kerja dengan tuntutan beban kerja. Peningkatan kapasitas kerja dilakukan dengan menambah karyawan yang memiliki kompetensi bekerja dilaut, dan bisa menyelam. Dengan demikian karyawan memiliki waktu yang cukup untuk melakukan kegiatan sosial, berinteraksi dengan keluarga dan melakukan kegiatan yang diminati untuk meredakan kepenatan akibat beban kerja yang tinggi.Kebijakan ini diharapkan menurunkan intensitas konflik pekerjaan- 
INOBIS: Jurnal Inovasi Bisnis dan Manajemen Indonesia

Volume 1, Nomor 3, Juni 2018

\section{Gusti Ayu Ari Warmadewi; Putu Saroyini Piartrini}

keluarga dan stres kerja. Karyawan diharapkan lebih nyaman karena mampu memenuhi berbagai peran dalam keluarga,melaksanakan berbagai aktivitas dengan keluarga, memberikan karyawan waktu istirahat dari pekerjaannya yang memerlukan banyak tenaga. Pelatihan terkait pelaksanan pekerjaan dilaut perlu diberikan agar karyawan memiliki keyakinan dalam melaksanakan pekerjaannya.

\section{Daftar Rujukan.}

Adkins, C. L., and Premeaux, S. F. 2012. Spending time: Theimpact of hours worked on work-family conflict. Journal of Vocational Behavior, 80(2), pp.380-389.

Afzal, Sidar and Farooqi, Yasir Aftab. 2014. Impact Of Work Family Conflict/Family Work Conflict On Job Satisfaction And Life Satisfaction: A Case Study Of A Public Sector University, Gujranwala Division, Pakistan. International Journal Of Multidisciplinary Sciences and Engineering, 5(8), pp.31-36.

Alazzam, Manar, PhD, RN, Raeda Fawzi Abualrub, PhD, RN and Ala H. Nazzal, MSN, RN. 2017. The Relationship Between Work-Family Conflict and Job Satisfaction Among Hospital Nurses. Nursing Forum, 0(0), pp.1-11.

Alves, Marcia Guimaraes De Mello., Dora Chor, Eduardo Faerstein, dan Claudia de S Lopes. 2004. Short version of "job stress scale": a Portuguase-language adaption. Rev Saude Publica, 38(2), pp.1-7.

Anggasta Bhull, Giovanny dan Margaretha, Melly. 2013. Pengaruh Work-Family Conflict terhadap Komitmen Organisasi: Kepuasan Kerja Sebagai Variabel Mediasi. Jurnal Manajemen,13(1), hal.15-34.

Cahyono, Dwi Han. 2014. Pengaruh lingkungan kerja, konflik kerja, stres kerja serta kepemimpinan terhadap kinerja karyawan di PT. Telkom Indonesia Tbk, Area Denpasar. Jurnal Buletin Studi Ekonomi. 19(1), hal.39-48.

Dewe, philip j, mochael p. O'Driscoll dan cary L. Cooper. 2012. Theories of psychologikal stress at work. pp. 23-38.

Gao, Y., Shi, J., \& Wang, L. 2013.Work-family conflict and job satisfaction: Emotional intelligence as a moderator. Stress Health, 29(3), pp.222-228.

Gati, Gilang Rastu dan Handoko, Hani. 2016. Pengaruh Konflik Pekerjaan Keluarga Terhadap Kepuasan Kerja Dengan Stres Kerja Sebagai Pemediasi (Studi Pt Perkebunan Nusantara 12). Tesis Magister Jurusan Manajemen pada Fakultas Ekonomika dan Bisnis. Universitas Gadjah Mada.

Ghozali, Imam. 2013. Aplikasi Analisis Multivariate dengan Program IBM SPSS 21. Semarang : UNDIP.

Gozukara, Izlem.,and Nurden Colakoglu. 2015. The Impact of Manager Support and WorkFamily Conflict on Job Satisfaction. Business Management Dynamics, 5(6), pp.13-25.

Han, Che dan Salit, I Gusti Ketut Netra.2014. Pengaruh Konflik terhadap stres kerja dan kepuasan kerja karyawan. E-Jurnal Manajemen Universitas Udayana. 3(8), pp.21502166.

Husein, Umar. 2008. Metode Penelitian untuk Skripsi dan Tesis Bisnis. Jakarta : PT Raja Grafindo Persada.

Husein, Umar. 2011. Riset Sumber Daya Manusia Dalam Organisasi. Jakarta: PT Gramedia Pustaka Utama, Jakarta.

Iqbal, Muhammad and Muhammad Adam Waseem. 2012. Impact of Job Stress on Job Satisfaction among Air Traffic Controllers of Civil Authority: An Empirical Study from Pakistan. International Journal of Human Resouce Studies, 2(2), pp. 53-70 
INOBIS: Jurnal Inovasi Bisnis dan Manajemen Indonesia

Volume 1, Nomor 3, Juni 2018

\section{Gusti Ayu Ari Warmadewi; Putu Saroyini Piartrini}

Jamadin, Nurnazirah, Samsiah Mohamad, Zurwina Syarkawi and Fauziah Noordin. 2014. Work - Family Conflict and Stress: Evidence from Malaysia. Journal of Economics, Business dan Management, 3(2), pp.309-312

Jung, C.S. 2014.Organizational goal ambiguity and job satisfaction in the public sector. Journal of Public Administration Research dan Theory, 24(4), pp.955-981.

Kahn, R. L., Wolfe, D. M., Quinn, R., Snoek, J. D., and Rosenthal, R. A. 1964.Organizational stress.Wiley: New York.

Kalliath, P., \& Kalliath, T. 2013. Work-family conflict and its impact on job satisfaction of social workers. British Journal of Social Work, 45 (1), pp.1-19.

Karasek., R. A. 1979. Job demands, job decision, attitude an mental strain: implication for job redesign. Administreative science quarterty. No.24.pp. 258-311.

Karasek., R. A. Dan Theorell T. 1990. Healthy work stress, productivity and the recontruction of working life. New York: Basic Books.

Khalidi, Doaa Al and Wazaify, Mayyada. 2013. Assessment of Pharmacusts Job Satisfaction and Job Related Stress in Amman. Journal Int J Clin Pharm, 32, pp.821-828.

Khamisa, N., Oldenburg, B., Peltzer, K., \& Ilic, D. 2015. Workrelated stress, burnout, job satisfaction and general health ofnurses. International Journal of Environmental Research and Public Health, 12, pp.652-666.

Khamisa, Natasha, Karl Peltzer, Dragan Ilic and Brian Oldenburg. 2017. Effect of personal and work stress on burnout, job satisfaction and general health of hospital nurses in south Africa. Journal of Health SA Gesondheid.22, pp.252-258.

Lee, S., Yun, T. and Lee, S.-Y. 2014. Moderating role of social support in the stressorsatisfaction relationship: evidence from police officers in Korea. International Review of Public Administration, 20(1), pp.102-116.

Mahfudz, Muhammad. 2017. Pengaruh Kepuasan Kerja dan Beban Kerja terhadap Kinerja Karyawan dan Stres Kerja sebagai Variabel Mediasi pada Karyawan Divisi Sales Consumer PT Bank Negara Indonesia (Persero) Tbk. Jurnla Eksekutif, 14(1), hal.51-75.

Mangkunegara, AP. 2011. Manajemen Sumber Daya Manusia Perusahaan. Bandung : PT Remaja Rosada Karya.

Mohannad Eid AbuRuz. 2014. A Comparation Between stress and job satisfaction in nurses and employee. Journal Annals of Biological Reseacrh, 3(6), pp.2888-2892.

Muamarah, Hanik Susilawati dan Indra Wijaya Kusuma. 2012. Pengaruh Iklim Etis Organisasi dan Stres Kerja terhadap Keinginan Berpindah dengan Kepuasan Kerja sebagai Variabel Intervening (Studi pada Account Representative dan Pemeriksaan Pajak di Kantor Pelayanan Pajak di Pulau Jawa). Jurnal BPPK, 5. hal.77-90.

Munandar, Ashar Sunyoto. (2012). Psikologi Industri dan Organisasi. Jakarta :UI-Press.

Netemeyer, R.G., Boles, J.S. and McMurrian, R. 1996. Development and validation of workfamily conflict and family-work conflict scales. Journal of Applied Psychology, 81(4), pp.400-410.

Putra, Bonaventura Ridya. 2012. Pengaruh Job Stressor terhadap Turnover Intention dengan Kepuasan Kerja sebagai Variabel Pemediasi. Jurnal Studi Manajemen Indonesia,1(2), hal.72-82

Rajak, Adnan. 2013. Pengaruh Konflik Interpersonal, Work-Family Conflict dan Stres Terhadap Kepuasan Kerja dan Dampaknya Terhadap Kepuasan Hidup. Jurnal Siasat Bisnis, 17(2), hal.131-156.

Rathi, Neerpal and Barath M. 2012. Work-Family Conflict and Job and Family Saticfaction: Moderating Effect of Social Support amoung Police Personel. Working Paper, 12(3). 
INOBIS: Jurnal Inovasi Bisnis dan Manajemen Indonesia

Volume 1, Nomor 3, Juni 2018

I Gusti Ayu Ari Warmadewi; Putu Saroyini Piartrini

Sekol, M. S., and Kim, S. C. 2014. Job satisfaction, burnout, andstress among pediatric nurses in various specialty units at anacute care hospital. Journal of Nursing Education and Practice, 4(12), pp.115-124.

Shacklock, K., \& Brunetto, Y. 2012. The intention to continue nursing: Work variables affecting three nurse generations in Australia. Journal of Advanced Nursing, 68(1), pp.36-46.

Singh, Rashmi and Nayak, Jogendra Kumar. 2015. Mediating role of stress between workfamily conflict and job satisfaction among the police officials : moderating role of social support. Journal of police strategies \& management, 38(4), pp.738-753.

Srimulyani, Veronika Agustini dan Prasetian, Ardhika Vicki.2014. Pengaruh Mediasi Kepuasan Kerja pada Hubungan Work-Family Conflict dan Komitmen Organisasional.Jurnal Ilmu Manajemen, 11(3), hal.95-109.

Tziner, Aharon and Sharoni, Gil. 2014. Organizational citizenship behavior, organizational justice, job stress and work family conflict: examination of their interrelationship with respondents from a non-western culture. Journal of Work dan Organizational Psychology, 30, pp.35-34. 